\title{
Organisational Change towards Servitization: A Theoretical Framework
}

\author{
Ali Ziaee Bigdeli ${ }^{\text {a }}$, Tim Baines ${ }^{a}$, Oscar F. Bustinza ${ }^{b}$, and Victor Guang Shi ${ }^{\mathrm{c}}$ \\ ${ }^{a}$ Aston Business School, Aston University, Birmingham, B4 7ET, UK. \\ $b$ University of Granada, Granada, SPAIN. \\ ${ }^{c}$ Advanced Manufacturing Research Centre University of Sheffield, Rotherham, S60 5TZ, UK.
}

\begin{abstract}
Purpose - The need for a holistic framework for studying organisational transformation towards servitization is implicit. This is particularly relevant as servitization demands consideration of both business model and organisational change. The aim of this paper is, therefore, to provide an integrative framework that systematically captures and evaluate existing literature on servitization.

Design/methodology/approach - The aim of the paper has achieved through three main objectives; comprehensively examine the literature in organisational change management that would assist with the selection of the most effective evaluation framework, classify previous studies against the proposed framework through a systematic literature review methodology, and analyse the selected papers and propose research questions/propositions based on the identified gaps.
\end{abstract}

Findings - Results indicate that there are two somewhat macro opportunities for the servitization community, including stronger infusion of generic theory into the servitization debate; and exploring servitization in action through the lens of the theoretical framework.

Practical Implications - The findings of the paper demonstrate the gaps in the servitization literature, which indeed require further theoretical/empirical research.

Originality/Value - It is discussed the usefulness and practicality of viewing research contributions that are setting out to be either 'descriptive' or 'prescriptive'. Consequently we have proposed several avenues for future research based on these two viewpoints.

Keywords - Servitization, Organisational change, Organisational transformation, Systematic literature review

Article Classification - Literature review 


\section{Introduction}

Manufacturing and service industries are often seen as largely independent. Whether discussing national economies, business classifications, education, training or employment, they tend to be thought of as separate (Bustinza et al., 2013). Yet manufacturers themselves can base their competitive strategies on services (Baines and Lightfoot, 2013; Lehtimäki and Karintaus, 2013), and the process through which this is achieved is commonly known as servitization (Vandermerwe and Rada, 1989; Baines et al., 2009a). From an academic perspective this is an increasing stream of literature, which in the recent years some efforts have been devoted on guiding future research avenues on the topic (see for example Vendrell-Herrero et al., 2014). The servitization of manufacturing firm cuts across several disciplines and communities such as product-service systems, service marketing, service operation, and service science. (Lightfoot et al., 2013). It is therefore a field of research studied from a broad range of academic traditions where most research does not question the implicit assumptions underlying service-led growth in product firms (Kowalkoski et al., 2014).

The topic of servitization also demands consideration of both business model and organisational change (Bigdeli et al., 2015). Under the process of organisational change, business model innovation plays an important role as successful change is based on the consistency between a company's strategy and all its structural elements, being business model able to realign these elements (Kindström, 2010a). It can be argued that a holistic approach is lacking as servitization also covers different levels of the organisation content (Kastalli et al., 2013) and contingency factors in the organisational environment context (Turunen and Finne, 2014). From all these process, content and context dimensions associated to servitization, a holistic framework should be actively sought in order to better understand this concept.

The paper proceeds as follows. We first describe a review of organisational change frameworks. Next, we present the details of the CCP perspective employed in this paper followed by the research methodology and results. The final section includes the discussion of results, implications, future research and limitations.

\section{Organisational Change Framework to review Servitization}

Developing a holistic framework that evaluates organisational change has been an enduring quest of scholars in management studies for years. Todnem By (2005) argues that theoretical 
frameworks and approaches to organisational change management are often contradictory, many of which focus on specific level or parameter of change. One plausible explanation may be that change researchers are inattentive to systematically and simultaneously look at all variables that are important in organisational change effort (Self et al., 2007).

There are several prominent models that focus mainly on the "content" variables of the change. These frameworks mainly focus on factors such as strategic orientation, organisational structure, and the impacts of employees on the change process (Armenakis and Bedeian, 1999). For instance, Burke and Litwin (1992) offer a model of change that distinguishes between transformational and transactional dynamics of organisation and explains how individual behaviours, and psychological variables are influenced the effort of change; Kanter (2003) suggests ten commandments for organisational change to emphasises what should be changed through analysing different layers of an organisation.

To get a broad picture of change process, Pettigrew (2012) emphasises that analysing the links between organisational change and the "context" in which it is embedded is inevitable. Hence, in an another stream, there are models that concentrate on contextual dynamics of organisational change and deal with responses taken in reacting to external and internal changes (Armenakis and Bedeian, 1999). These models mainly focus on circumstances factors that influence organisational effectiveness. For instance, Haveman (1992) analysed the legislative and technological impacts on organisational change and proposed that in response to unexpected environmental change a shift in organisational structure and activities will increase short-term financial performance and long-term sustainability. In an another contextual-focused study, Cross et al. (2013) explained the importance of network analysis as a significant tool that would facilitate organisational change.

A third stream of models of organisation change attempt to address the how question. More specifically, they proposed explicit methods to formulate and implement the "process" of change. This process encompasses the phases through which successful organizational changes progress (Self et al., 2007). Research on the process of change has its roots in the primary model that was proposed by Lewin (1947) that compromised unfreezing, moving, and freezing phases. Several other scholars (e.g. (Armenakis et al., 2000, Kotter and Cohen, 2002) elaborated on Lewin's classic change model for practitioners to use as a framework for introducing organisational change. In a similar strain,

In this study, rather than following a topical scheme emphasising specific consideration of change, we elected to simultaneously focus on the three overarching research themes i.e. 
content, context, and process common to all organisational change efforts. Note that, only a handful organisational change models bring together these variables. Prominent amongst these is the CCP framework proposed by Pettigrew (1988), and later by Whipp et al., (1989), and Pye and Pettigrew (2005).

This holistic approach to studying transformation provides a robust platform for investigating the literature on servitization and has therefore been adopted for this study. The CCP framework is broad enough to accommodate the myriad ideas and arguments about servitization, which emphasises that the change process involves not only the content of a chosen strategy, or the process which reveals various content alternatives, but also the contexts in which it occurs. Thus, the "why" of change is derived from an analysis of inner and outer context, the "what" of change is encapsulated under content, and the "how" of change can be understood from an analysis of the process (Pye and Pettigrew, 2005, Whipp et al., 1989).

\section{Content of change}

A fundamental factor in any evaluation study is an understanding of "what is being evaluated". In the scope of this research, the evaluation of servitization can be conducted within different level of activities within an organisation. The most common distinction between the levels of aggregation proposed in strategic change literature is between the functional level, business level, and corporate level (Wit et al., 2010, Wheelen and Hunger, 2011). These are somewhat traditional categorisations in the literature, and in recent years have been extended to include the network of an organisation. The functional level is concerned with developing and nurturing competence to provide the business units or the entire company with a competitive advantage, while the business level emphasises the enhancement of the competitive position of a corporation's products or services within a specific industry service by a specific business unit. The network level explains the situation where two or more firms move beyond a mere transactional relationship and work jointly towards a shared goal (Kohtamäki, Partanen et al. 2013).

\section{Context of change}

Changes in organisation take place in response to both circumstances, and the existing external and internal conditions that have been shown to influence organisational effectiveness (Paton and McCalman, 2008). Pettigrew's (1988) framework suggests that two aspects of "context" should be considered while evaluating a change: (1) the inner context 
which refers to the factors from within the firm through which ideas for change has to proceed, and (2) the outer context which refers to the factors from outside the organisation. More recently within the strategic change literature (e.g. (Kelly and Amburgey, 1991, Hatch, 2012), Pettigrew (1988), Pye and Pettigrew (2005), or Hatch 2012) these factors have been extended to include (internal) organisational structure, corporate culture, power and leadership, political characteristics, strategic directions, level of trust, and stage of the board development, and (external) political, economic, social, technological, regulations, environmental, and industry.

\section{Process of transformation}

Process are the "how" factors of change effort and specific methods/models employed to formulate and implement an organisational change (Self et al., 2007). According to Armenakis and Bedeian (1999), process of organisational changes is a set of actions needed to accomplish an intended change. Pettigrew (1988) proposed that the process of change is influenced by the organisation's change formulation and implementation strategies, properly defining the start and end point, and the role of technology in the process. Formulation strategy is an intentional process that includes pathways between identifiable decisions events and the outcomes of these decisions (Pettigrew, 1977). It is also related to the methods that capture staged or delayed impacts of strategy over time (Shayne-Gary, 2005), being the implementation the way to convert strategic alternatives into an operating plan (Aaker, 1988). The role of technology facilitates knowledge flow, allowing interdependencies in the change process, and redefining the boundary between the firm and its surrounding environment (Chesbrough, 2003). Furthermore, there is an important factor to be considered in the process analysis: the role of business models. Business models are strongly related to servitization as financing may not be as prominent and assume that knowledge is cognitively limited by a firm previous success (Chesbrough and Rosenbloom, 2002).

\section{Descriptive and prescriptive}

Along with the categories and sub-categories of the CCP framework, two additional classifications were considered in our proposed framework to improve the practical implications. Since servitization literature entails a range of different topics, we find it helpful to view research contributions that are setting out to be either 'descriptive' or 'prescriptive'. The former deals with establishing theories and how change has taken place, whereas 
prescriptive refers to proposed ideas and how the change can be carried out. In this regard, descriptive research differs from normative prescriptive research that is principally concerned with questions on how the reality should be. Prescriptive papers are useful due to the "increasingly unstable environment in which organisations operate" (Lee et al., 2000, pp. 549), as it is the case of servitizing firms (Eggert et al., 2014). Clearly these distinctions are interlinked and complimentary, but academics and scientists tend to be drawn to descriptive contributions and evidence to help the understanding the world around us, whereas practitioners are frequently seeking prescriptions to overcome their businesses problems.

A comprehensive view of the framework proposed can be seen on Table 1. 
Ziaee Bigdeli, A., Baines, T., Bustinza, O.F. and Guang Shi, V., 2017. Organisational Change towards Servitization: A Theoretical

Framework. Competitiveness Review: An International Business Journal, 27(1). pp. 12 - 39

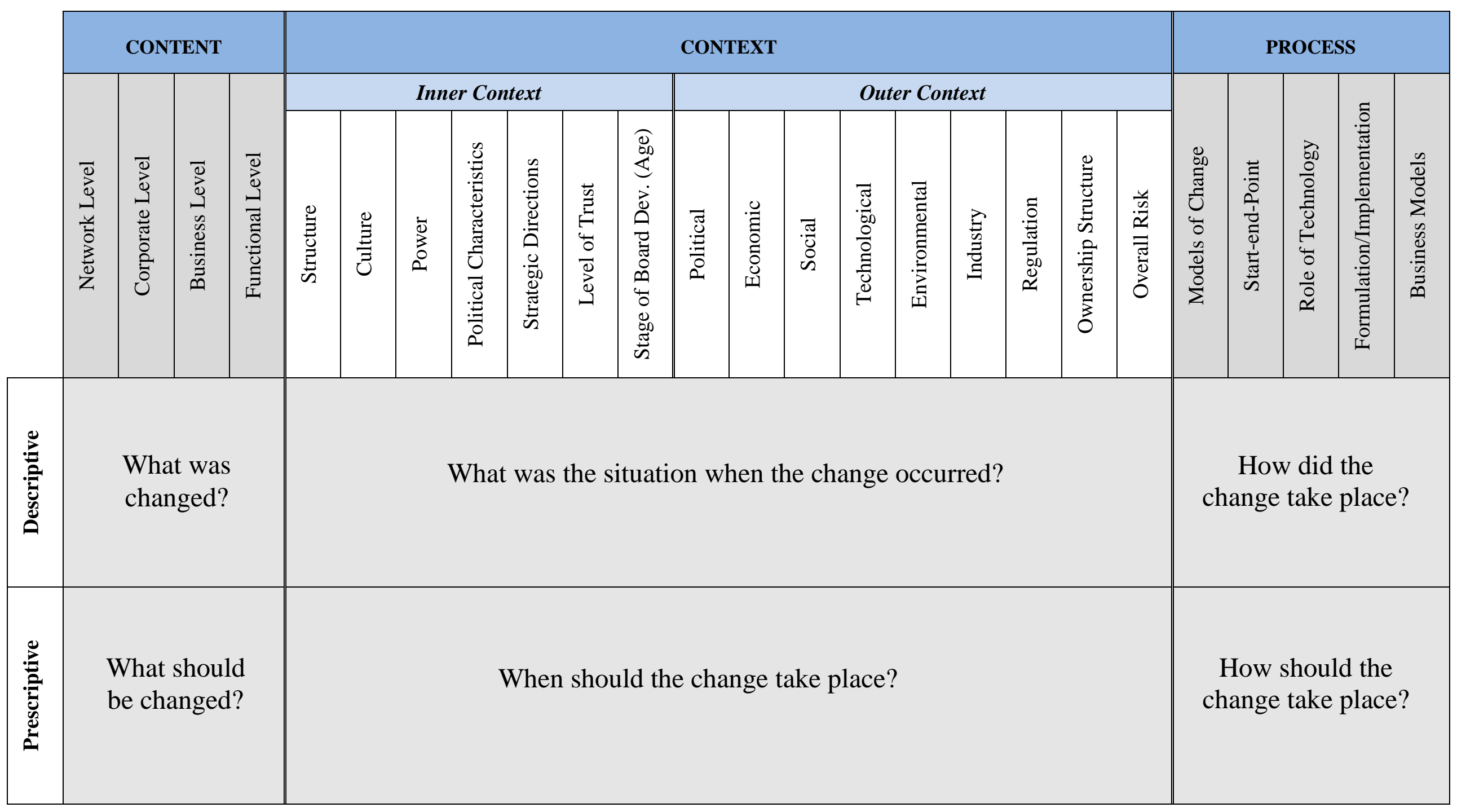

Table 1. The theoretical framework developed to identify and classify servitization research 
Ziaee Bigdeli, A., Baines, T., Bustinza, O.F. and Guang Shi, V., 2017. Organisational Change towards Servitization: A Theoretical Framework. Competitiveness Review: An International Business Journal, 27(1).pp. $12-39$

\section{Methodology}

The theoretical framework illustrated in Table 1 is intended to guide the identification and review of literature and, through this process, enable the research landscape to be interpreted. The challenge is to reliably populate this framework, and so a systematic literature review methodology was adopted. This approach, which initially proposed by Tranfield et al. (2003), has been designed to manage the diversity of knowledge for a specific academic inquiry, which would then enable the researcher both to map and to assess the existing intellectual territories and to specify research questions to develop existing body of knowledge further. Although this evidence-based approach has been traditionally used in medical science research, the movement to base practice on the best available evidence has migrated to other disciplines including the management field.

The three main principle and generic guidelines of the systematic review process applied in this study included : (1) a detailed planning of the review with a precise definition of the aim and objectives to be addressed in the course of the review, (2) a rigorous conduction of the review comprising the identification and selection of relevant studies, applying particular criteria for inclusion and exclusion supported by an appraisal of the quality of the reviewed studies and the strength of their findings, and (3) reporting and disseminating the review results.

Establishing the study scope presents challenges. One of the critical problems regarding the topic of servitization is that different scholars tend to use different term to describe the transformation towards advanced services (Baines et al., 2009b), and the boundary of those terms is still blurred (Hou and Neely, 2013). Therefore, in order to be more focused, the scope of the searches were only emphasised on the term "servitization". Note that since the searches were conducted in the entire body of the selected papers (e.g. title, keyword, literature review, references, etc.), other relevant topics to servitization including ProductService Systems (PSS), service science, service operation, advanced services etc. were automatically included in our samples.

By using leading databases including Scopus, Web of Science, ProQuest, ABI Inform and Emerald, that comprehensively envelop the research communities around servitization, we gathered a total of 302 peer-reviewed journal papers written in English and published during 1988 and November 2014. Three researchers manually screened the titles, abstracts, keywords, and contents of each of the papers and excluded all manuscripts that (1) lacked a clear contribution to the servitization research and just focused on the term as an example to 
explain another subject/issue, (2) focused on pure service industries such as tourism, (3) focused only on after-sales services, and (4) focused on topics such as sustainability and supply chain management without a clear reference to servitization. Our clustering was further validated through a full post article review of the final pool of core articles and were recorded and stored in an electronic repository using an Excel spreadsheet. Taken together, these steps condensed the literature sample to a final set of 158 relevant research articles published in 74 journals that formed the evidence base of our review. The researchers carried out the reading of these articles in their entirety to understand the research methodology and principal contribution, and this information was used to position the paper within the subcategories of the theoretical framework (i.e. content, context, and process).The papers in each subcategory were then reviewed more thoroughly to establish the relative 'maturity' of contributions, but also to confirm that the initial categorisation was appropriate.

\section{Results and Analysis of Research Contributions}

In this section we report on the distribution of the 158 research publications gathered through the systematic literature review method against the proposed framework.

\section{Research exploring the 'Content' of servitization}

Papers grouped under the content category comprises of four levels of activities (Table 2). The network level focuses on analysing the impact of servitization on networking activities different industries (Bikfalvi, Lay et al. 2013). Also, the current research agenda towards the configuration of activities and value creations amongst business networks (or as some suggested business ecosystems) discusses a swift transition of management mentalities from traditional product-focused supply chain optimization to the alignment of service value chain, where the customers role as value creator is a central feature of the construct (Bustinza et al., 2013).

In the corporate level, several studies examine product-service business development by small- and medium-sized equipment manufacturers (SMEMs) and focus on underlying dynamic and operational capabilities in service business development (Paiola, Gebauer et al. 2012). In this line, Gebauer and Fleisch (2007) emphasised the corporate decisions towards servitization and examined that comprehensive understanding of the service market helps managers to realise that services can generate a major part of the value proposition in manufacturing companies. 
The general theme of the papers in the business level content is the links between the operational activities of organisations' business units and transformation towards servitization. For instance, by conducting several case studies Johnson and Mena (2008) explored the challenges and opportunities that face the supply chain management activities within organisations that are pursuing a servitization strategy. In addition, significant evidence exists in addressing the convergence of crafted operational configuration and advanced technologies (Baines and Lightfoot, 2014). The research contribution at the functional level has focused on the specific functional aspects of an organisation including sales, marking, communication, etc. In this regard, Turunen and Toivonen (2011) examined the relationship between servitization and customer relationship management. They argued that although earlier literature has emphasized the positive effects of a separate service unit, their comparative case study indicates that a separate unit as such does not guarantee success in service business.

\begin{tabular}{|c|c|c|c|c|c|}
\hline & & Network Level & Corporate Level & Business Level & Functional Level \\
\hline \multirow[b]{2}{*}{ : } & 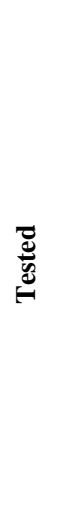 & $\begin{array}{l}\text { (Guo and Ng, 2011, } \\
\text { Kohtamäki et al., 2013b, } \\
\text { Roehrich and Caldwell, 2012, } \\
\text { Aloini et al., 2013, Wikhamn et } \\
\text { al., 2013, Thomas et al., 2009, } \\
\text { Srai, 2011, Pawar et al., 2009, } \\
\text { Bastl et al., 2012, Johnstone et } \\
\text { al., 2009, Chakkol et al., 2014, } \\
\text { Kucza and Gebauer, 2011, } \\
\text { Nordin et al., 2013a, Lockett et } \\
\text { al., 2011, Baines et al., 2011, } \\
\text { Ahlström and Nordin, 2006, } \\
\text { Toossi et al., 2013, Gebauer et } \\
\text { al., 2010d, Smith et al., 2012, } \\
\text { Bikfalvi et al., 2013, Lin and } \\
\text { Lin, 2012) }\end{array}$ & $\begin{array}{l}\text { (Gebauer and Fleisch, 2007, } \\
\text { Paiola et al., 2012, Windahl } \\
\text { and Lakemond, 2006, Eggert } \\
\text { et al., 2014, Suarez et al., } \\
\text { 2013, Neely, 2009, Baines et } \\
\text { al., 2010, Christensen, 2013) }\end{array}$ & $\begin{array}{l}\text { (Kastalli et al., 2013, Datta } \\
\text { and Roy, 2010, Falk, 2014, } \\
\text { Raja et al., 2010, Johnstone } \\
\text { et al., 2014, Kohtamäki et al., } \\
\text { 2013a, Jääskeläinen and } \\
\text { Laihonen, 2014, Smith et al., } \\
\text { 2014, Baines and Lightfoot, } \\
\text { 2014, Parry et al., 2012, } \\
\text { Johnson and Mena, 2008, } \\
\text { Cavalieri et al., 2007, Kujala } \\
\text { et al., 2013, Gebauer et al., } \\
\text { 2011, Ejermo and Bergman, } \\
\text { 2014, Lay et al., 2010, Wang, } \\
\text { 2014, Brax, 2005, Gremyr et } \\
\text { al., 2010, Johnstone et al., } \\
\text { 2008) }\end{array}$ & $\begin{array}{l}\text { (Teixeira et al., } \\
\text { 2012, Wang et al., } \\
\text { 2013, Turunen and } \\
\text { Toivonen, 2011) }\end{array}$ \\
\hline & 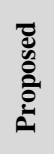 & & & (Tan et al., 2010) & \\
\hline 离 & 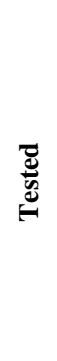 & $\begin{array}{l}\text { (Li et al., 2014a, Wang and } \\
\text { Durugbo, 2013, Kapletia and } \\
\text { Probert, 2010, Macdonald et } \\
\text { al., 2011, Sun et al., 2012, } \\
\text { Mills et al., 2013, Saccani et } \\
\text { al., 2014, Xie et al., 2014, } \\
\text { Caldwell et al., 2009, } \\
\text { Kleemann and Essig, 2013, } \\
\text { Caniato et al., 2014, Finne and } \\
\text { Holmström, 2013, Bustinza et } \\
\text { al., 2013) }\end{array}$ & $\begin{array}{l}\text { (Vandermerwe and Rada, } \\
\text { 1988, Raddats and } \\
\text { Easingwood, 2010, Lodefalk, } \\
\text { 2014, Robinson et al., 2002) }\end{array}$ & $\begin{array}{l}\text { (Baines et al., 2009a, Ulaga } \\
\text { and Reinartz, 2011, Lemke et } \\
\text { al., 2011, Panizzolo, 2008) }\end{array}$ & $\begin{array}{l}\text { (Lin et al., 2014, } \\
\text { Teixeira et al., 2013) }\end{array}$ \\
\hline
\end{tabular}




\begin{tabular}{|c|c|c|c|c|}
\hline 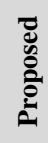 & $\begin{array}{l}\text { (Li et al., 2014b, Kumar and } \\
\text { Kumar, 2004) }\end{array}$ & $\begin{array}{l}\text { (Gebauer et al., 2012b, } \\
\text { Hypko et al., 2010, Colen } \\
\text { and Lambrecht, 2013) }\end{array}$ & $\begin{array}{l}\text { (Allmendinger and } \\
\text { Lombreglia, 2005, Settanni et } \\
\text { al., 2014) }\end{array}$ & $\begin{array}{l}\text { (Li et al., 2014b, } \\
\text { Kumar and Kumar, } \\
\text { 2004) }\end{array}$ \\
\hline
\end{tabular}

Table 2. Content

\section{Research exploring the 'Context' of servitization}

Papers grouped under this category offer contributions on the factors that determine why organisations carry out servitization and who influence the management decisions. We take into account the inner context variables (Table 3 ) and the outer context variables (Table 4) to synthesise the contributions of identified papers. Papers in the inner context principally focus on the impacts of internal situations/environment on the transformation towards servitization. Concerning the organisational structure, Oliva et al. (2012), through conducting an empirical study, suggested that the creation of a separate service organisation as a profit center has a significant positive mediating effect on the managerial commitment towards delivering advanced services. Moreover, Gebauer, et al. (2009) articulated the relationship between organisational structure and service-orientation strategies within manufacturing firms that provide product. The authors discussed that whether companies should integrate or separate service and product functions in order to achieve service orientation. Several other studies concentrated on the strategic directions of the organisation. Specifically, strategic directions to maintain revenue streams and improve profitability (Baines et al., 2009), and the cocreation strategies that firms would follow in order to become financially sustainable while moving towards servitization (Roser, DeFillippi et al. 2013)

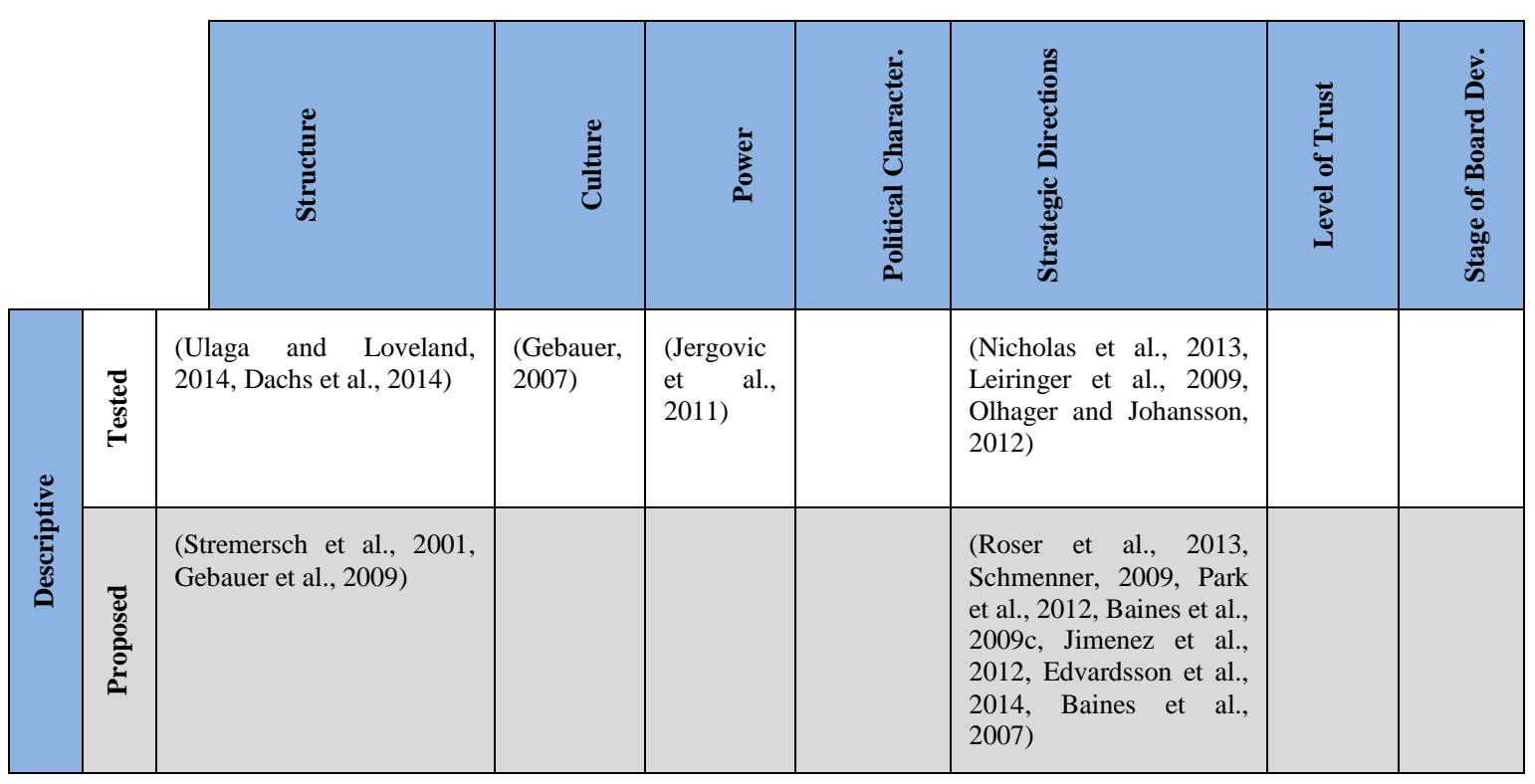




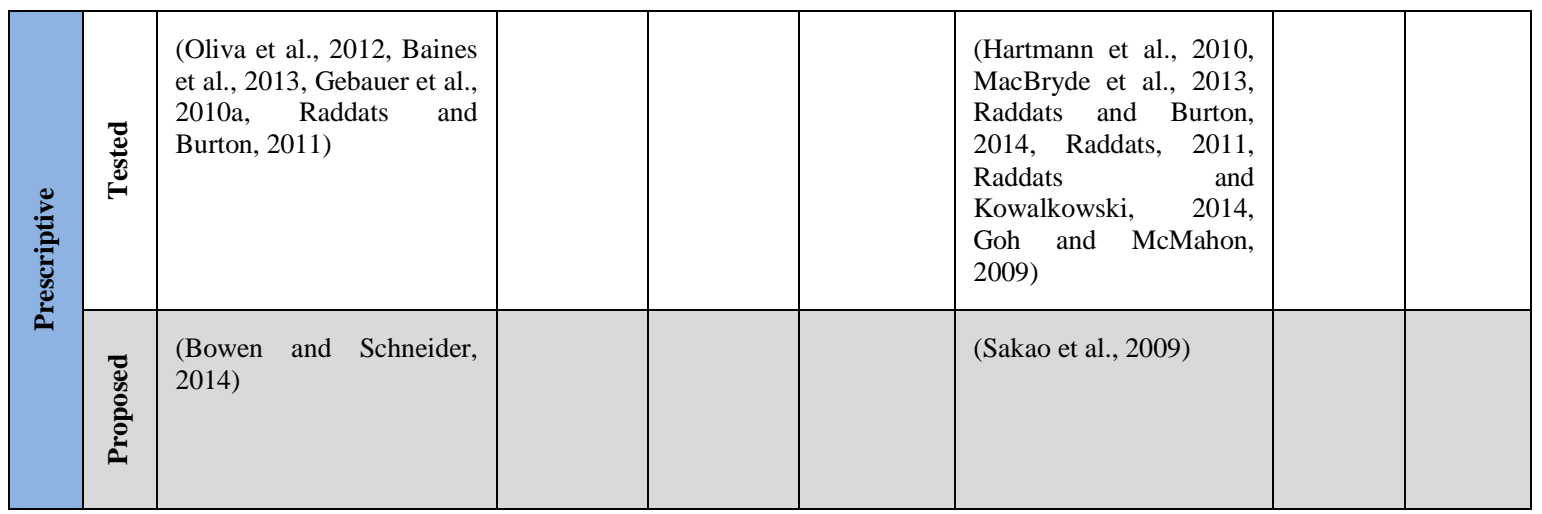

Table 3. Inner Context

Complementary to the inner context, we also examined the existing studies covering the effects of external factors on servitization (Table 4). On the political level, the studies mainly focused on describing the impacts of political determination on the institutional characteristics of organisations that facilitate or hinder the efforts towards delivering advanced services (Mont, 2004). Several studies examined the economic implications of servitization, covered from firm-level competitive bidding for service contracts (Kreye et al., 2013), to national level GDP growth in developing and emerging economies (Kim and Yoon, 2014; Macbeth and de Opacua, 2010), to re-shoring benefit in advanced economies (Bailey and De Propris, 2014). Moreover, a number of papers prescribed servitization as a promising business model in addressing environmental and social challenges (Gaiardelli et al., 2014). On the more prescriptive side, by adopting an institutional economic perspective, Araujo and Spring (2006) argued that the economic structures determine the outcome of servitization, rather than just technical criteria, such as features of the product or services. Some studies have also tackled environmental, sustainability issues, for example, Resta et al., (2009) examined Life Cycle Analysis (LCA) based method can be applied to extend producer responsibility in addressing balanced economic and environmental benefit. Moreover, some studies examined the influence of the industry on the adoption of advanced services. For instance, Turunen and Finne (2014) adopted contingency theory and organisational ecology theory, and evaluated the propositions including the effects of population density, competing populations, resource dependency, and institutional linkages. 


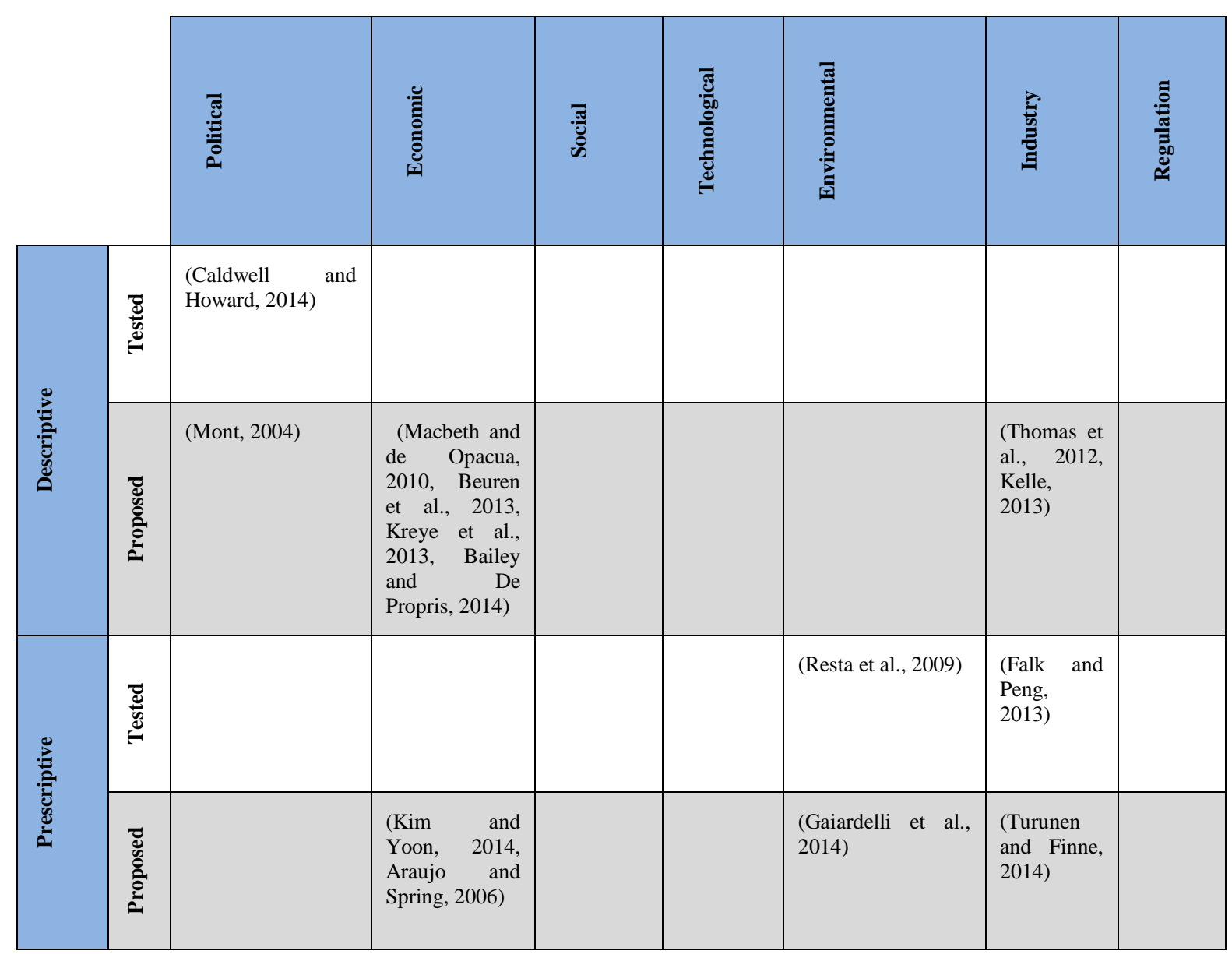

Table 4. Outer Context

\section{Research exploring the 'process' of servitization}

The reviewed literature samples comprise a set of research papers on the process of servitization. These papers are categorised into five specific themes under the process (Table 5). We identified a number of studies that examined the role of business models and business model innovation in achieving organisational change towards servitization (Barquet et al., 2013; or Spring and Araujo, 2009). Concerning the star-end point of servitization, the selected studies have offered very different perspectives, involving sequential perspectives and an organic development approach. The sequential approach point out service maturity stages: (1) the methods based, decoupled stage; (2) the asset-based, semi-integrated stage; and (3) the services-based, integrated stage (Hartmann et al., 2014). 


\begin{tabular}{|c|c|c|c|c|c|c|}
\hline & Models of Change & Business Models & $\begin{array}{l}\text { Start-End } \\
\text { Point }\end{array}$ & $\begin{array}{c}\text { Role of } \\
\text { Technology }\end{array}$ & Formulation / Implementation \\
\hline \multirow[t]{2}{*}{ 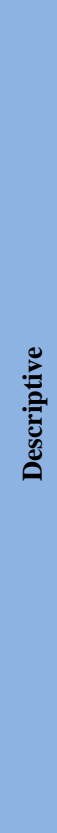 } & 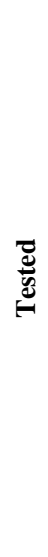 & $\begin{array}{l}\text { (Kothamali et al., } \\
\text { 2013; Suarez et al., } \\
\text { 2013) }\end{array}$ & $\begin{array}{l}\text { (Davies et al., 2007, } \\
\text { Spring and Araujo, 2013, } \\
\text { Meier et al., 2010a, } \\
\text { Greenough and Grubic, } \\
\text { 2011, AlSaidi and Mo, } \\
\text { 2013, Bastl et al., 2012, } \\
\text { Kujala et al., 2010, } \\
\text { Kindström and } \\
\text { Kowalkowski, 2014, } \\
\text { Laperche and Picard, } \\
\text { 2013, Gaiardelli et al., } \\
\text { 2014, Witell and } \\
\text { Löfgren, 2013, Davies et } \\
\text { al., 2006, Fernandes, } \\
\text { 2012, Johnsen et al., } \\
\text { 2009, Tongur and } \\
\text { Engwall, 2014) }\end{array}$ & $\begin{array}{l}\text { (Clayton et } \\
\text { al., 2012) }\end{array}$ & $\begin{array}{l}\text { (Adeogun et } \\
\text { al., 2010, } \\
\text { Minerva et al., } \\
\text { 2013, Laine et } \\
\text { al., 2010, Lee } \\
\text { et al., 2013, } \\
\text { Smith, 2013) }\end{array}$ & $\begin{array}{l}\text { Visintin, 2012, Lindberg and } \\
\text { Nordin, 2008, Durugbo, 2014, } \\
\text { Kujala et al., 2011, An et al., } \\
\text { 2008, Kerley et al., 2011, Lim } \\
\text { et al., 2012, Van Ostaeyen et } \\
\text { al., 2013, Carreira et al., 2013, } \\
\text { Bandinelli and Gamberi, 2011, } \\
\text { Martinez et al., 2010, Nordin et } \\
\text { al., 2013b, Ng and Nudurupati, } \\
\text { 2010, Gebauer et al., 2010c, } \\
\text { Holmström et al., 2010, Laine et } \\
\text { al., 2012, Rapaccini et al., 2013) }\end{array}$ \\
\hline & 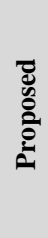 & & $\begin{array}{l}\text { (Wild, 2010, Spring and } \\
\text { Araujo, 2009, Oliva and } \\
\text { Kallenberg, 2003, Bask } \\
\text { et al., 2011, Goldhar and } \\
\text { Berg, 2010) }\end{array}$ & & $\begin{array}{l}\text { (Chae, 2014, } \\
\text { Sheth and } \\
\text { Sharma, 2008, } \\
\text { Daim et al., } \\
\text { 2010, Grubic, } \\
\text { 2014, Geum et } \\
\text { al., 2011) }\end{array}$ & $\begin{array}{l}\text { (Roy and Cheruvu, 2009, Baron } \\
\text { et al., 2014, Liu et al., 2014, } \\
\text { Godlevskaja et al., 2011, } \\
\text { Mathieu, 2001, Velamuri et al., } \\
\text { 2011, Brown et al., 2011, Yang } \\
\text { et al., 2010, Chae, 2012, } \\
\text { Ponsignon et al., 2012) }\end{array}$ \\
\hline \multirow[t]{2}{*}{ 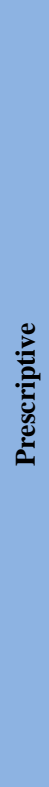 } & 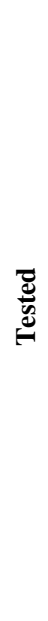 & $\begin{array}{l}\text { (Vijnik and Van } \\
\text { Looy, 2013) }\end{array}$ & $\begin{array}{l}\text { Meier et al., 2010b, } \\
\text { Cook, 2014, Kindström, } \\
\text { 2010b, Barquet et al., } \\
\text { 2013, Storbacka, 2011, } \\
\text { Storbacka et al., 2013, } \\
\text { Dimache and Roche, } \\
\text { 2013, Zhen, 2012, Shen } \\
\text { et al., 2012, Geum and } \\
\text { Park, 2011, Gebauer et } \\
\text { al., 2012a, Barnett et al., } \\
\text { 2013) }\end{array}$ & $\begin{array}{l}\text { (Hartmann et } \\
\text { al., 2014) }\end{array}$ & $\begin{array}{l}\text { McFarlane } \\
\text { and Cuthbert, } \\
\text { 2012, Neff et } \\
\text { al., 2014, } \\
\text { Durugbo, } \\
\text { 2013, } \\
\text { Belvedere et } \\
\text { al., 2013, } \\
\text { Kowalkowski } \\
\text { et al., 2013a, } \\
\text { Santamaría et } \\
\text { al., 2012) }\end{array}$ & $\begin{array}{l}\text { (Tukker, 2004, Pezzotta et al., } \\
\text { 2012, Datta et al., 2013, Alix } \\
\text { and Zacharewicz, 2012, Paiola } \\
\text { et al., 2013, Angelis et al., 2012, } \\
\text { Wise and Baumgartner, 1999, } \\
\text { Kowalkowski et al., 2013b, Sun } \\
\text { et al., 2011, Erkoyuncu et al., } \\
\text { 2013, Sun, 2010, Azarenko et } \\
\text { al., 2009, Kumar and Markeset, } \\
\text { 2007, Gebauer, 2009, } \\
\text { Kindström and Kowalkowski, } \\
\text { 2009, Ng et al., 2012, Lightfoot } \\
\text { and Gebauer, 2011, Fischer et } \\
\text { al., 2010, Matthyssens and } \\
\text { Vandenbempt, 2010, Klaus and } \\
\text { Maklan, 2012, Neu and Brown, } \\
\text { 2005, Gebauer et al., 2010b, } \\
\text { Auguste et al., 2006, Kreye et } \\
\text { al., 2014) }\end{array}$ \\
\hline & 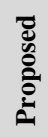 & & $\begin{array}{l}\text { (Phumbua and Tjahjono, } \\
\text { 2012) }\end{array}$ & & & (Biege et al., 2012) \\
\hline
\end{tabular}

Table 5. Process

Several studies have concentrated on the enabling role of technology for servitization adoption (Belvedere et al., 2013; Durugbo, 2013). For example, Geum et al., (2011) proposed a customization framework for product-service road mapping according to the technological interface involved. In particular, manufacturing sectors increasingly adopt remote monitoring technologies to create value for the customers (Daim et al., 2010). Studies also proposed the 
role of technologies impacts upon evolution of sales organisation (Sheth and Sharma, 2008). For instant, improvement in customer contact through the use of ICT and precision analytics, has transformed traditional sales into customer-focused organisation and global account management teams. (Sheth and Sharma, 2008).

Related to formulation/implementation strategy process, some authors proposed key constructs related to product-service bundles development (Baron et al.2014), examined typologies of product-service bundles (Tukker, 2004), evaluated the structure and sequence of the phases to develop those bundles (Pezzotta et al., 2013), analysed delivery approaches to address customers (Visintin, 2012), evaluated the challenges experienced by firms during the servitization journey (Martinez et al., 2010), or assessed the key elements related to a successful servitization strategy implementation (Rapaccini et al., 2013).

\section{Discussion}

Based on the findings of the literature review, papers have been classified into each of the main subcategories (i.e. Content, Context or Process) according to their main research contribution(s). Analysing the four subcategories of "Content" reveals a higher proportion of descriptive studies, particularly concentrating on the business and network level. Among the main key topics analysed, it is possible to find papers studying the role of CRM, the effect of servitization on financial performance or networked impact. With regards to the prescriptive papers, Baines et al., (2009) adopt structural and infrastructural perspectives in operations management; they captured a set of operations principles, structures and processes that serve as a practical guide for a manufacturer in the delivery of product-centric serviced offering. Covering network level, there are few prescriptive studies as Fine and Holmstrom (2013), exploring the supply chain's ability to provide industrial services, or Sun et al. (2012) developing a quantitative evaluation method based on service providers and service receivers. Finally, moving on to the corporate level, Hypko et al. (2010) proposed that the industrial equipment and machinery manufacturers need to consider retaining the ownership in selling capabilities or Performance-based contracts. To sum up, prescriptive papers cover topic as supply chain structure or value co-creation among others.

Considering the analysis of inner context, most of the papers are focused on the strategic directions and structural dimensions related to the servitization decisions. This is the case of Olhager and Johansson (2012) establishing that new goods manufacturing and service operations used the same long-term capacity strategy and planning strategy. Power dynamics, level of trust, or stage of board development have not been considered under a descriptive or 
prescriptive way. With regards outer analysis, most of the papers are focused on the economic and industrial aspects of servitization. For example, Beuren et al. (2013) stating that PSS aims at sustainability through balancing environmental, economic, and social aspects. In contrast, a very limited number of papers examine the social, environmental, or political dimensions. Moreover, we were unable to locate studies addressing the technological, regulatory or ownership structures in both a descriptive or prescriptive orientation.

With regards to the servitization process, literature review emphasises the importance of formulation/implementation of strategy and the prominent role of business models and technology/innovation. Nevertheless, models of change -as methods to asset the effect of strategy implementation on a regular base- have the final objective of increasing performance. There are few papers analysing the final effect of servitization strategy on performance (Suarez et al., 2013; or Vijnik and Van Looy, 2013), and the results are contradictory. Besides, there are authors such as Kowalkowski et al. (2014) claiming to rethink the established assumptions about the positive benefits of servitization. Furthermore, there is an important lack in papers studying the start-end point analysis, claiming for further research on monitoring firms before and after servitization implementation. In summary, we found that most of the studies are concentrated on the servitization design, delivery and procurement processes, business models and innovation, scenario simulations, decision making process, or new service development.

\section{Contributions and Future Studies}

This paper has focused on servitization as a process of organisational change, and adopted an established theoretical framework proposed by Pettigrew (1988). Based on a systematic literature review (Tranfield et al. 2003), we classified the relevant 158 papers published between 1988 and 2014 against this framework. The analysis of this classification has then allowed us to identify the strengths and weaknesses in the research landscape, and synthesise the agenda for further research.

There are however two somewhat macro opportunities that we see for the servitization community, and these are as follows and pertain to the current overall body of knowledge on servitization.

- Stronger infusion of generic theory into the servitization debate; servitization is a cross-cutting theme, and many linkages exist with established topics across engineering and management. Our review has been constrained to the core literature 
on servitization, this having been completed, it would now be valuable to repeat this exercise to identify and draw links with established theoretical contributions in allied areas. A publication based on such analysis would provide an extremely valuable platform for the servitization community.

- Exploring servitization in action through the lens of the theoretical framework; in particular, a macro study that dynamically compared and contrast, the processes of industrial transformation, with the knowledge base captured in the theoretical framework. Many facets of servitization would be reviled, some of which would undoubtedly be dealt with by contributions captured in the framework, but there would also be others that do not feature. This process would not only lead to identifying specific research opportunities, but also enable the theoretical framework itself to be refined. This would contribute to the research community dealing with change management, and ultimately deliver a holistic roadmap for manufactures embarking on the servitization process.

Furthermore, as discussed, we find it helpful to view research contributions are setting out to be either 'descriptive' or 'prescriptive'. Consequently we propose the following opportunities for descriptive research to better understand the:

- Effect of servitization implementation on the performance of the firm. In particular, model the relationship between variables such as product maturity, regulatory and fiscal environment, installed base, size of organisation, and competitors.

- Importance of outer context of the firm on the adoption of servitization. In particular, political characteristics, level of intra-organisational trust, social implications of servitization, and overall risks.

- Forms of servitization. Our ideas are coalescing around services being either base, intermediate or advanced, but tactically what are the routes that manufacturers follow? In particular, model the relationship between external environment and internal competences.

- Organisational transformation pathways. How do manufacturers innovate? What barriers do they encounter? How do they navigate these? What lessons do they ultimately learn that can be generically applied?

Prescriptive research should help to better deal with: 
- Identify the opportunities for value creation within customers. How to go about mapping risk and reward as service offerings change. How to assess the role of business partners and technology providers.

- Messaging and demonstrating value to the customer and within their own organisation. How to evidence value and how to communicate this to stakeholders within the organisation, customers and financial sponsors.

- Acquisitions, alliances and mergers. When to form these. How to identify opportunities and threats to intellectual property. How to deal with technology partners, especially for ICT capabilities, and how to decide when to insource these.

- Risks and costs. How to identify possible risks, and how to model the costs associated with mitigating these. How to price offerings.

- Managing customers. How to identify and engage stakeholders at customers? How to educate them and communicate a value proposition based around servitization?

Policy makers and academics increasingly considerer that manufacturing firms should innovate in products and services offerings in order to compete through other variables than just cost (Porter and Ketels, 2003; Neely, 2009). The current research helps them to further understand the entire set of variables that configure any strategic position according to the organisational context. Those variables included in the outer context are more interesting for policy makers as it is where they can be more influent. In this line, papers related to political, industrial or social variables on external context can be specially indicated (see Roehrich and Caldwell, 2012; Caldwell and Howard, 2014; or Hartmann et al., 2014). The revision of these variables also allow to suggest further research about the role of regulators to support manufacturing sectors, the role played by Knowledge-Intensive Business Services (KIBS) as elements to build servitized local ecosystems, or the role of cluster policies to promote servitization.

Additional future lines of research should be considering the heterogeneity of context as the determinant of success in servitization, or studying the different strategies to be applied according to the industrial context and the position in the value chain. Moreover, some assumptions about servitization need to be contrasted as the ability to appropriate value from innovative business models related to services, or the effect on the performance of manufacturing firms. 


\section{References}

Adeogun, O., Tiwari, A. \& Alcock, J. R. (2010). "Informatics-based product-service systems for point-of-care devices". CIRP Journal of Manufacturing Science and Technology, 3, 107-115.

Åhlström, P. \& Nordin, F. (2006). "Problems of establishing service supply relationships: Evidence from a high-tech manufacturing company". Journal of Purchasing and Supply Management, $12,75-89$.

Alix, T. \& Zacharewicz, G. (2012). "Product-service systems scenarios simulation based on GDEVS/HLA: Generalized discrete event specification/high level architecture". Computers in Industry, 63, 370-378.

Allmendinger, G. \& Lombreglia, R. (2005). "Four strategies for the age of smart services". harvard business review, 83, 131.

Aloini, D., Dulmin, R., Mininno, V. \& Ponticelli, S. (2013). "Project-service solutions in the yacht industry: A value-chain analysis". International Journal of Engineering Business Management, 5.

Alsaidi, M. S. \& Mo, J. P. T. (2013). "An empirical approach to model formulation for system support engineering". International Journal of Engineering Business Management, 5, 1-15.

An, Y., Lee, S. \& Park, Y. (2008). "Development of an integrated product-service roadmap with QFD: A case study on mobile communications". International Journal of Service Industry Management, 19, 621-638.

Angelis, J., Parry, G. \& Macintyre, M. (2012). "Discretion and complexity in customer focused environments". European Management Journal, 30, 466-472.

Araujo, L. \& Spring, M. (2006). "Services, products, and the institutional structure of production". Industrial Marketing Management, 35, 797-805.

Armenakis, A. A. \& Bedeian, A. G. (1999). "Organizational change: A review of theory and research in the 1990s". Journal of management, 25, 293-315.

Armenakis, A. A., Harris, S. G. \& Feild, H. S. (2000). "Making change permanent A model for institutionalizing change interventions". Research in organizational change and development, $12,97-128$.

Auguste, B. G., Harmon, E. P. \& Pandit, V. (2006). "The right service strategies for product companies". McKinsey Quarterly, 1, 40.

Azarenko, A., Roy, R., Shehab, E. \& Tiwari, A. (2009). "Technical product-service systems: some implications for the machine tool industry". Journal of Manufacturing Technology Management, 20, 700-722.

Bailey, D. \& De Propris, L. (2014). "Reshoring: Opportunities and limits for manufacturing in the UK - The case of the auto sector". Revue d'Economie Industrielle, 145, 45-61.

Baines, T., Lightfoot, H., Peppard, J., Johnson, M., Tiwari, A., Shehab, E. \& Swink, M. (2009a). "Towards an operations strategy for product-centric servitization". International Journal of Operations and Production Management, 29, 494-519.

Baines, T., Lightfoot, H. \& Smart, P. (2011). "Servitization within manufacturing: Exploring the provision of advanced services and their impact on vertical integration". Journal of Manufacturing Technology Management, 22, 947-954.

Baines, T., Lightfoot, H., Smart, P. \& Fletcher, S. (2013). "Servitization of manufacture: Exploring the deployment and skills of people critical to the delivery of advanced services". Journal of Manufacturing Technology Management, 24, 637-646.

Baines, T. \& Lightfoot, H. W. (2014). "Servitization of the manufacturing firm: Exploring the operations practices and technologies that deliver advanced services". International Journal of Operations and Production Management, 34, 2-35.

Baines, T. S., Lightfoot, H., Benedettini, O., Whitney, D. \& Kay, J. M. (2010). "The adoption of servitization strategies by UK-based manufacturers". Proceedings of the Institution of Mechanical Engineers, Part B: Journal of Engineering Manufacture, 224, 815-829.

Baines, T. S., Lightfoot, H. W., Benedettini, O. \& Kay, J. M. (2009b). "The servitization of manufacturing: a review of literature and reflection on future challenges". Journal of Manufacturing Technology Management, 20, 547-567. 
Baines, T. S., Lightfoot, H. W., Evans, S., Neely, A., Greenough, R., Peppard, J., Roy, R., Shehab, E., Braganza, A., Tiwari, A., Alcock, J. R., Angus, J. P., Basti, M., Cousens, A., Irving, P., Johnson, M., Kingston, J., Lockett, H., Martinez, V., Michele, P., Tranfield, D., Walton, I. M. \& Wilson, H. (2007). "State-of-the-art in product-service systems". Proceedings of the Institution of Mechanical Engineers, Part B: Journal of Engineering Manufacture, 221, 15431552.

Baines, T. S., Lightfoot, H. W. \& Kay, J. M. (2009c). "Servitized manufacture: Practical challenges of delivering integrated products and services". Proceedings of the Institution of Mechanical Engineers, Part B: Journal of Engineering Manufacture, 223, 1207-1215.

Bandinelli, R. \& Gamberi, V. (2011). "Servitization in oil and gas sector: Outcomes of a case study research". Journal of Manufacturing Technology Management, 23, 87-102.

Barnett, N. J., Parry, G., Saad, M., Newnes, L. B. \& Goh, Y. M. (2013). "Servitization: Is a Paradigm Shift in the Business Model and Service Enterprise Required?". Strategic Change, 22, 145156.

Baron, S., Warnaby, G. \& Hunter-Jones, P. (2014). "Service(s) marketing research: Developments and directions". International Journal of Management Reviews, 16, 150-171.

Barquet, A. P. B., De Oliveira, M. G., Amigo, C. R., Cunha, V. P. \& Rozenfeld, H. (2013). "Employing the business model concept to support the adoption of product-service systems (PSS)". Industrial Marketing Management, 42, 693-704.

Bask, A., Lipponen, M., Rajahonka, M. \& Tinnilä, M. (2011). "Framework for modularity and customization: Service perspective". Journal of Business and Industrial Marketing, 26, 306319.

Bastl, M., Johnson, M., Lightfoot, H. \& Evans, S. (2012). "Buyer-supplier relationships in a servitized environment: An examination with Cannon and Perreault's framework". International Journal of Operations and Production Management, 32, 650-675.

Belvedere, V., Grando, A. \& Bielli, P. (2013). "A quantitative investigation of the role of Information and Communication Technologies in the implementation of a product-service system". International Journal of Production Research, 51, 410-426.

Beuren, F. H., Gomes Ferreira, M. G. \& Cauchick Miguel, P. A. (2013). "Product-service systems: A literature review on integrated products and services". Journal of Cleaner Production, 47, 222-231.

Biege, S., Lay, G. \& Buschak, D. (2012). "Mapping service processes in manufacturing companies: Industrial service blueprinting". International Journal of Operations and Production Management, 32, 932-957.

Bigdeli, A. Z., Baines, T., Bustinza, O. F. \& Guang Shi, V. (2015) Published. "Holistic approach to evaluating servitization: A content, context, process framework". EurOMA 2015 Neuchâtel, Switzerland.

Bikfalvi, A., Lay, G., Maloca, S. \& Waser, B. R. (2013). "Servitization and networking: Large-scale survey findings on product-related services". Service Business, 7, 61-82.

Bowen, D. E. \& Schneider, B. (2014). "A Service Climate Synthesis and Future Research Agenda". Journal of Service Research, 17, 5-22.

Brax, S. (2005). "A manufacturer becoming service provider - Challenges and a paradox". Managing Service Quality, 15, 142-155.

Brown, B., Sichtmann, C. \& Musante, M. (2011). "A model of product-to-service brand extension success factors in B2B buying contexts". Journal of Business and Industrial Marketing, 26, 202-210.

Burke, W. W. \& Litwin, G. H. (1992). "A causal model of organizational performance and change". Journal of management, 18, 523-545.

Bustinza, O. F., Parry, G. C. \& Vendrell-Herrero, F. (2013). "Supply and demand chain management: The effect of adding services to product offerings". Supply Chain Management, 18, 618-629.

Caldwell, N. \& Howard, M. (2014). "Contracting for complex performance in markets of few buyers and sellers: The case of military procurement". International Journal of Operations and Production Management, 34, 270-294. 
Caldwell, N. D., Roehrich, J. K. \& Davies, A. C. (2009). "Procuring complex performance in construction: London Heathrow Terminal 5 and a Private Finance Initiative hospital". Journal of Purchasing and Supply Management, 15, 178-186.

Caniato, F., Luzzini, D. \& Ronchi, S. (2014). "Purchasing performance management systems: An empirical investigation". Production Planning and Control, 25, 616-635.

Carreira, R., Patrício, L., Jorge, R. N. \& Magee, C. L. (2013). "Development of an extended Kansei engineering method to incorporate experience requirements in product-service system design". Journal of Engineering Design, 24, 738-764.

Cavalieri, S., Gaiardelli, P. \& Ierace, S. (2007). "Aligning strategic profiles with operational metrics in after-sales service". International Journal of Productivity and Performance Management, $56,436-455$.

Chae, B. (2012). "A framework for new solution development: An adaptive search perspective". Service Industries Journal, 32, 127-149.

Chae, B. (2014). "A complexity theory approach to IT-enabled services (IESs) and service innovation: Business analytics as an illustration of IES". Decision Support Systems, 57, 1-10.

Chakkol, M., Johnson, M., Raja, J. \& Raffoni, A. (2014). "From goods to solutions: How does the content of an offering affect network configuration?". International Journal of Physical Distribution and Logistics Management, 44, 132-154.

Christensen, J. L. (2013). "The ability of current statistical classifications to separate services and manufacturing". Structural Change and Economic Dynamics, 26, 47-60.

Clayton, R. J., Backhouse, C. J. \& Dani, S. (2012). "Evaluating existing approaches to product-service system design: A comparison with industrial practice". Journal of Manufacturing Technology Management, 23, 272-298.

Colen, P. J. \& Lambrecht, M. R. (2013). "Product service systems: Exploring operational practices". Service Industries Journal, 33, 501-515.

Cook, M. (2014). "Fluid transitions to more sustainable product service systems". Environmental Innovation and Societal Transitions, 12, 1-13.

Cross, R., Ernst, C. \& Pasmore, B. (2013). "A bridge too far? How boundary spanning networks drive organizational change and effectiveness. ". Organizational Dynamics, Organizational Dynamics, 81-91.

Dachs, B., Biege, S., Borowiecki, M., Lay, G., Jäger, A. \& Schartinger, D. (2014). "Servitisation of European manufacturing: evidence from a large scale database". Service Industries Journal, 34, 5-23.

Daim, T. U., Jetter, A., Demirkan, H. \& Maglio, P. P. (2010). "Perspective: Technology Management in the Service Sector". International Journal of Services, Technology and Management, 13, 3 19.

Datta, P. P. \& Roy, R. (2010). "Cost modelling techniques for availability type service support contracts: A literature review and empirical study". CIRP Journal of Manufacturing Science and Technology, 3, 142-157.

Datta, P. P., Srivastava, A. \& Roy, R. (2013). "A simulation study on maintainer resource utilization of a fast jet aircraft maintenance line under availability contract". Computers in Industry, 64, 543-555.

Davies, A., Brady, T. \& Hobday, M. (2006). "Charting a path toward integrated solutions". MIT Sloan Management Review, 47, 39-48.

Davies, A., Brady, T. \& Hobday, M. (2007). "Organizing for solutions: Systems seller vs. systems integrator". Industrial marketing management, 36, 183-193.

Dimache, A. \& Roche, T. (2013). "A decision methodology to support servitisation of manufacturing". International Journal of Operations and Production Management, 33, 14351457.

Durugbo, C. (2013). "Competitive product-service systems: Lessons from a multicase study". International Journal of Production Research, 51, 5671-5682.

Durugbo, C. (2014). "Strategic framework for industrial product-service co-design: Findings from the microsystems industry". International Journal of Production Research, 52, 2881-2900.

Edvardsson, B., Kleinaltenkamp, M., Tronvoll, B., Mchugh, P. \& Windahl, C. (2014). "Institutional logics matter when coordinating resource integration". Marketing Theory, 14, 291-309. 
Eggert, A., Hogreve, J., Ulaga, W. \& Muenkhoff, E. (2014). "Revenue and Profit Implications of Industrial Service Strategies". Journal of Service Research, 17, 23-39.

Ejermo, O. \& Bergman, K. (2014). "Services vs. Manufacturing - How Does Foreign and Domestic Sales Impact on Their R\&D?". Journal of Industry, Competition and Trade, 14, 367-391.

Erkoyuncu, J. A., Durugbo, C., Shehab, E., Roy, R., Parker, R., Gath, A. \& Howell, D. (2013). "Uncertainty driven service cost estimation for decision support at the bidding stage". International Journal of Production Research, 51, 5771-5788.

Falk, M. (2014). "The impact of new goods and service products on firm growth: Evidence from Austrian-linked firm-level data". Economics of Innovation and New Technology, 23, 378-397.

Falk, M. \& Peng, F. (2013). "The increasing service intensity of European manufacturing". Service Industries Journal, 33, 1686-1706.

Fernandes, K. J. (2012). "A framework for service systems analysis: Theory and practice". Production Planning and Control, 23, 480-497.

Finne, M. \& Holmström, J. (2013). "A manufacturer moving upstream: Triadic collaboration for service delivery". Supply Chain Management, 18, 21-33.

Fischer, T., Gebauer, H., Gregory, M., Ren, G. \& Fleisch, E. (2010). "Exploitation or exploration in service business development?: Insights from a dynamic capabilities perspective". Journal of Service Management, 21, 591-624.

Gaiardelli, P., Resta, B., Martinez, V., Pinto, R. \& Albores, P. (2014). "A classification model for product-service offerings". Journal of cleaner production, 66, 507-519.

Gebauer, H. (2007). "Extending the service business in China: Experience of Swiss companies". Singapore Management Review, 29, 59-71.

Gebauer, H. (2009). "An attention-based view on service orientation in the business strategy of manufacturing companies". Journal of Managerial Psychology, 24, 79-98.

Gebauer, H., Edvardsson, B. \& Bjurko, M. (2010a). "The impact of service orientation in corporate culture on business performance in manufacturing companies". Journal of Service Management, 21, 237-259.

Gebauer, H., Edvardsson, B., Gustafsson, A. \& Witell, L. (2010b). "Match or mismatch: Strategystructure configurations in the service business of manufacturing companies". Journal of Service Research, 13, 198-215.

Gebauer, H., Fischer, T. \& Fleisch, E. (2010c). "Exploring the interrelationship among patterns of service strategy changes and organizational design elements". Journal of Service Management, 21, 103-129.

Gebauer, H. \& Fleisch, E. (2007). "An investigation of the relationship between behavioral processes, motivation, investments in the service business and service revenue". Industrial Marketing Management, 36, 337-348.

Gebauer, H., Gustafsson, A. \& Witell, L. (2011). "Competitive advantage through service differentiation by manufacturing companies". Journal of Business Research, 64, 1270-1280.

Gebauer, H., Paiola, M. \& Edvardsson, B. (2010d). "Service business development in small and medium capital goods manufacturing companies". Managing Service Quality, 20, 123-139.

Gebauer, H., Paiola, M. \& Edvardsson, B. (2012a). "A capability perspective on service business development in small and medium-sized suppliers". Scandinavian Journal of Management, 28, 321-339.

Gebauer, H., Pütz, F., Fischer, T. \& Fleisch, E. (2009). "Service orientation of organizational structures". Journal of Relationship Marketing, 8, 103-126.

Gebauer, H., Ren, G. J., Valtakoski, A. \& Reynoso, J. (2012b). "Service-driven manufacturing: Provision, evolution and financial impact of services in industrial firms". Journal of Service Management, 23, 120-136.

Geum, Y., Lee, S., Kang, D. \& Park, Y. (2011). "Technology roadmapping for technology-based product-service integration: a case study". Journal of Engineering and Technology management, 28, 128-146.

Geum, Y. \& Park, Y. (2011). "Designing the sustainable product-service integration: a productservice blueprint approach". Journal of Cleaner Production, 19, 1601-1614. 
Godlevskaja, O., Van Iwaarden, J. \& Van Der Wiele, T. (2011). "Moving from product-based to service-based business strategies: Services categorisation schemes for the automotive industry". International Journal of Quality and Reliability Management, 28, 62-94.

Goh, Y. M. \& Mcmahon, C. (2009). "Improving reuse of in-service information capture and feedback". Journal of Manufacturing Technology Management, 20, 626-639.

Goldhar, J. \& Berg, D. (2010). "Blurring the boundary: Convergence of factory and service processes". Journal of Manufacturing Technology Management, 21, 341-354.

Greenough, R. M. \& Grubic, T. (2011). "Modelling condition-based maintenance to deliver a service to machine tool users". International Journal of Advanced Manufacturing Technology, 52, $1117-1132$.

Gremyr, I., Löfberg, N. \& Witell, L. (2010). "Service innovations in manufacturing firms". Managing Service Quality, 20, 161-175.

Grubic, T. (2014). "Servitization and remote monitoring technology: A literature review and research agenda". Journal of Manufacturing Technology Management, 25, 6-6.

Guo, L. \& Ng, I. (2011). "The co-production of equipment-based services: An interpersonal approach". European Management Journal, 29, 43-50.

Hartmann, A., Davies, A. \& Frederiksen, L. (2010). "Learning to deliver service-enhanced public infrastructure: Balancing contractual and relational capabilities". Construction Management and Economics, 28, 1165-1175.

Hartmann, A., Roehrich, J., Frederiksen, L. \& Davies, A. (2014). "Procuring complex performance: The transition process in public infrastructure". International Journal of Operations and Production Management, 34, 174-194.

Hatch, M. J. (2012). Organization theory: modern, symbolic and postmodern perspectives, Oxford university press.

Haveman, H. A. (1992). "Between a rock and a hard place: Organizational change and performance under conditions of fundamental environmental transformation". Administrative Science Quarterly, 48-75.

Holmström, J., Brax, S. \& Ala-Risku, T. (2010). "Comparing provider-customer constellations of visibility-based service". Journal of Service Management, 21, 675-692.

Hou, J. \& Neely, A. (2013). "Barriers of Servitization: Results of a Systematic Literature".

Hypko, P., Tilebein, M. \& Gleich, R. (2010). "Benefits and uncertainties of performance-based contracting in manufacturing industries: An agency theory perspective". Journal of Service Management, 21, 460-489.

Jääskeläinen, A. \& Laihonen, H. (2014). "Applying performance measurement in service operations: Analysis of contextual differences". International Journal of Business Performance Management, 15, 243-261.

Jergovic, A., Vucelja, A., Inic, B. \& Petrovic, Z. (2011). "Transformation of business entities - from production to service company". Technics Technologies Education Management, 6, 118-127.

Jimenez, B., Angelov, B. \& Rao, B. (2012). "Service Absorptive Capacity: Its Evolution and Implications for Innovation". Journal of the Knowledge Economy, 3, 142-163.

Johnsen, T., Howard, M. \& Miemczyk, J. (2009). "UK defence change and the impact on supply relationships". Supply Chain Management, 14, 270-279.

Johnson, M. \& Mena, C. (2008). "Supply chain management for servitised products: A multi-industry case study". International Journal of Production Economics, 114, 27-39.

Johnstone, S., Dainty, A. \& Wilkinson, A. (2008). "In search of 'product-service': Evidence from aerospace, construction, and engineering". Service Industries Journal, 28, 861-875.

Johnstone, S., Dainty, A. \& Wilkinson, A. (2009). "Integrating products and services through life: An aerospace experience". International Journal of Operations and Production Management, 29, 520-538.

Johnstone, S., Wilkinson, A. \& Dainty, A. (2014). "Reconceptualizing the service paradox in engineering companies: Is HR a missing link?". IEEE Transactions on Engineering Management, 61, 275-284.

Kanter, R. M. (2003). Challenge of organizational change: How companies experience it and leaders guide it, Simon and Schuster. 
Kapletia, D. \& Probert, D. (2010). "Migrating from products to solutions: An exploration of system support in the UK defense industry". Industrial Marketing Management, 39, $582-592$.

Kastalli, I. V., Van Looy, B. \& Neely, A. (2013). "Steering manufacturing firms towards service business model innovation". California Management Review, 56, 100-123.

Kelle, M. (2013). "Crossing industry borders: German manufacturers as services exporters". World Economy, 36, 1494-1515.

Kelly, D. \& Amburgey, T. L. (1991). "Organizational inertia and momentum: A dynamic model of strategic change". Academy of management journal, 34, 591-612.

Kerley, W., Wynn, D. C., Eckert, C. \& Clarkson, P. J. (2011). "Redesigning the design process through interactive simulation: A case study of life-cycle engineering in jet engine conceptual design". International Journal of Services and Operations Management, 10, 30-51.

Kim, B. \& Yoon, S. (2014). "Servitization of South Korea economy: Causes for sluggishness and policy issues". American Journal of Applied Sciences, 11, 1692-1702.

Kindström, D. (2010a). "Towards a service-based business model-Key aspects for future competitive advantage". European Management Journal, 28, 479-490.

Kindström, D. (2010b). "Towards a service-based business model - Key aspects for future competitive advantage". European Management Journal, 28, 479-490.

Kindström, D. \& Kowalkowski, C. (2009). "Development of industrial service offerings: A process framework". Journal of Service Management, 20, 156-172.

Kindström, D. \& Kowalkowski, C. (2014). "Service innovation in product-centric firms: A multidimensional business model perspective". Journal of Business and Industrial Marketing, 29, 96-111.

Klaus, P. P. \& Maklan, S. (2012). "EXQ: A multiple-item scale for assessing service experience". Journal of Service Management, 23, 5-33.

Kleemann, F. C. \& Essig, M. (2013). "A providers' perspective on supplier relationships in performance-based contracting". Journal of Purchasing and Supply Management, 19, 185198.

Kohtamäki, M., Partanen, J. \& Möller, K. (2013a). "Making a profit with R\&D services - The critical role of relational capital". Industrial Marketing Management, 42, 71-81.

Kohtamäki, M., Partanen, J., Parida, V. \& Wincent, J. (2013b). "Non-linear relationship between industrial service offering and sales growth: The moderating role of network capabilities". Industrial Marketing Management, 42, 1374-1385.

Kotter, J. P. \& Cohen, D. S. (2002). The heart of change: Real-life stories of how people change their organizations, Harvard Business Press.

Kowalkowski, C., Kindström, D. \& Gebauer, H. (2013a). "ICT as a catalyst for service business orientation". Journal of Business and Industrial Marketing, 28, 506-513.

Kowalkowski, C., Witell, L. \& Gustafsson, A. (2013b). "Any way goes: Identifying value constellations for service infusion in SMEs". Industrial Marketing Management, 42, 18-30.

Kreye, M. E., Newnes, L. B. \& Goh, Y. M. (2013). "Information availability at the competitive bidding stage for service contracts". Journal of Manufacturing Technology Management, 24, 976-997.

Kreye, M. E., Newnes, L. B. \& Goh, Y. M. (2014). "Uncertainty in competitive bidding-a framework for product-service systems". Production Planning and Control, 25, 462-477.

Kucza, G. \& Gebauer, H. (2011). "Global approaches to the service business in manufacturing companies". Journal of Business and Industrial Marketing, 26, 472-483.

Kujala, J., Ahola, T. \& Huikuri, S. (2013). "Use of services to support the business of a project-based firm". International Journal of Project Management, 31, 177-189.

Kujala, S., Artto, K., Aaltonen, P. \& Turkulainen, V. (2010). "Business models in project-based firms - Towards a typology of solution-specific business models". International Journal of Project Management, 28, 96-106.

Kujala, S., Kujala, J., Turkulainen, V., Artto, K., Aaltonen, P. \& Wikström, K. (2011). "Factors influencing the choice of solution-specific business models". International Journal of Project Management, 29, 960-970.

Kumar, R. \& Kumar, U. (2004). "Service delivery strategy: Trends in mining industries". International Journal of Surface Mining, Reclamation and Environment, 18, 299-307. 
Kumar, R. \& Markeset, T. (2007). "Development of performance-based service strategies for the oil and gas industry: A case study". Journal of Business and Industrial Marketing, 22, 272-280.

Laine, T., Paranko, J. \& Suomala, P. (2010). "Downstream shift at a machinery manufacturer: The case of the remote technologies". Management Research Review, 33, 980-993.

Laine, T., Paranko, J. \& Suomala, P. (2012). "Using a business game concept to enhance servitization: A longitudinal case study". Managing Service Quality, 22, 428-446.

Laperche, B. \& Picard, F. (2013). "Environmental constraints, Product-Service Systems development and impacts on innovation management: Learning from manufacturing firms in the French context". Journal of Cleaner Production, 53, 118-128.

Lay, G., Copani, G., Jäger, A. \& Biege, S. (2010). "The relevance of service in European manufacturing industries". Journal of Service Management, 21, 715-726.

Lee, J. H., Phaal, R. \& Lee, S. H. (2013). "An integrated service-device-technology roadmap for smart city development". Technological Forecasting and Social Change, 80, 286-306.

Leiringer, R., Green, S. D. \& Raja, J. Z. (2009). "Living up to the value agenda: The empirical realities of through-life value creation in construction". Construction Management and Economics, 27, 271-285.

Lemke, F., Clark, M. \& Wilson, H. (2011). "Customer experience quality: An exploration in business and consumer contexts using repertory grid technique". Journal of the Academy of Marketing Science, 39, 846-869.

Lewin, K. (1947). "Frontiers in group dynamics II. Channels of group life; social planning and action research". Human relations, 1, 143-153.

Li, G., Huang, F. F., Cheng, T. C. E., Zheng, Q. \& Ji, P. (2014a). "Make-or-buy service capacity decision in a supply chain providing after-sales service". European Journal of Operational Research, 239, 377-388.

Li, M., Wu, G. D. \& Lai, X. D. (2014b). "Capacity coordination mechanism for supply chain under supply-demand uncertainty". International Journal of Simulation Modelling, 13, 364-376.

Lightfoot, H., Baines, T. \& Smart, P. (2013). "The servitization of manufacturing: A systematic literature review of interdependent trends". International Journal of Operations \& Production Management, 33, 1408-1434.

Lightfoot, H. W. \& Gebauer, H. (2011). "Exploring the alignment between service strategy and service innovation". Journal of Service Management, 22, 664-683.

Lim, C. H., Kim, K. J., Hong, Y. S. \& Park, K. (2012). "PSS Board: A structured tool for productservice system process visualization". Journal of Cleaner Production, 37, 42-53.

Lin, F. J. \& Lin, Y. H. (2012). "The determinants of successful R\&D consortia: Government strategy for the servitization of manufacturing". Service Business, 6, 489-502.

Lin, W. J., Jiang, Z. B., Liu, R. \& Wang, L. (2014). "The bullwhip effect in hybrid supply chain". International Journal of Production Research, 52, 2062-2084.

Lindberg, N. \& Nordin, F. (2008). "From products to services and back again: Towards a new service procurement logic". Industrial Marketing Management, 37, 292-300.

Liu, C. H., Chen, M. C., Tu, Y. H. \& Wang, C. C. (2014). "Constructing a sustainable service business model: An S-D logic-based integrated product service system (IPSS)". International Journal of Physical Distribution and Logistics Management, 44, 80-97.

Lockett, H., Johnson, M., Evans, S. \& Bastl, M. (2011). "Product Service Systems and supply network relationships: An exploratory case study". Journal of Manufacturing Technology Management, 22, 293-313.

Lodefalk, M. (2014). "The role of services for manufacturing firm exports". Review of World Economics, 150, 59-82.

Macbeth, D. K. \& De Opacua, A. I. (2010). "Review of Services Science and possible application in rail maintenance". European Management Journal, 28, 1-13.

Macbryde, J., Paton, S. \& Clegg, B. (2013). "Understanding high-value manufacturing in Scottish SMEs". International Journal of Operations and Production Management, 33, 1579-1598.

Macdonald, E. K., Wilson, H., Martinez, V. \& Toossi, A. (2011). "Assessing value-in-use: A conceptual framework and exploratory study". Industrial Marketing Management, 40, 671682. 
Martinez, V., Bastl, M., Kingston, J. \& Evans, S. (2010). "Challenges in transforming manufacturing organisations into product-service providers". Journal of Manufacturing Technology Management, 21, 449-469.

Mathieu, V. (2001). "Service strategies within the manufacturing sector: Benefits, costs and partnership". International Journal of Service Industry Management, 12, 451-475.

Matthyssens, P. \& Vandenbempt, K. (2010). "Service addition as business market strategy: Identification of transition trajectories". Journal of Service Management, 21, 693-714.

Mcfarlane, D. \& Cuthbert, R. (2012). "Modelling information requirements in complex engineering services". Computers in Industry, 63, 349-360.

Meier, H., Roy, R. \& Seliger, G. (2010a). "Industrial Product-Service systems-IPS2". CIRP Annals Manufacturing Technology, 59, 607-627.

Meier, H., Roy, R. \& Seliger, G. (2010b). "Industrial Product-Service Systems—IPS < sup > $2</$ sup $>$ ". CIRP Annals-Manufacturing Technology, 59, 607-627.

Mills, J., Purchase, V. C. \& Parry, G. (2013). "Enterprise imaging: Representing complex multiorganizational service enterprises". International Journal of Operations and Production Management, 33, 159-180.

Minerva, R., Manzalini, A., Moiso, C. \& Crespi, N. (2013). "Virtualizing network". Lecture Notes in Computer Science (including subseries Lecture Notes in Artificial Intelligence and Lecture Notes in Bioinformatics).

Mont, O. (2004). "Institutionalisation of sustainable consumption patterns based on shared use". Ecological economics, 50, 135-153.

Neely, A. (2009). "Exploring the financial consequences of the servitization of manufacturing". Operations Management Research, 1, 103-118.

Neff, A. A., Hamel, F., Herz, T. P., Uebernickel, F., Brenner, W. \& Vom Brocke, J. (2014). "Developing a maturity model for service systems in heavy equipment manufacturing enterprises". Information and Management, 51, 895-911.

Neu, W. A. \& Brown, S. W. (2005). "Forming successful business-to-business services in goodsdominant firms". Journal of Service Research, 8, 3-17.

Ng, I., Parry, G., Smith, L., Maull, R. \& Briscoe, G. (2012). "Transitioning from a goods-dominant to a service-dominant logic: Visualising the value proposition of Rolls-Royce". Journal of Service Management, 23, 416-439.

Ng, I. C. L. \& Nudurupati, S. S. (2010). "Outcome-based service contracts in the defence industry mitigating the challenges". Journal of Service Management, 21, 656-674.

Nicholas, J., Ledwith, A. \& Bessant, J. (2013). "Reframing the search space for radical innovation". Research Technology Management, 56, 27-35.

Nordin, F., Brozovic, D. \& Holmlund, M. (2013a). "Disintermediation in Business-to-Business Service Channels: Mechanisms and Challenges". Journal of Business-to-Business Marketing, 20, 179-192.

Nordin, F., Lindahl, I. \& Brege, S. (2013b). "The Applicability of Integrated Solutions Offerings: Differential Effects of Product Complexity". Journal of Relationship Marketing, 12, 59-78.

Olhager, J. \& Johansson, P. (2012). "Linking long-term capacity management for manufacturing and service operations". Journal of Engineering and Technology Management - JET-M, 29, 2233.

Oliva, R., Gebauer, H. \& Brann, J. M. (2012). "Separate or Integrate? Assessing the Impact of Separation Between Product and Service Business on Service Performance in Product Manufacturing Firms". Journal of Business-to-Business Marketing, 19, 309-334.

Oliva, R. \& Kallenberg, R. (2003). "Managing the transition from products to services". International journal of service industry management, 14, 160-172.

Paiola, M., Gebauer, H. \& Edvardsson, B. (2012). "Service Business Development in Small- to Medium-Sized Equipment Manufacturers". Journal of Business-to-Business Marketing, 19, 33-66.

Paiola, M., Saccani, N., Perona, M. \& Gebauer, H. (2013). "Moving from products to solutions: Strategic approaches for developing capabilities". European Management Journal, 31, 390409. 
Panizzolo, R. (2008). "A methodology to measure the value of services provided to customers in manufacturing firms". Measuring Business Excellence, 12, 3-15.

Park, Y., Geum, Y. \& Lee, H. (2012). "Toward integration of products and services: Taxonomy and typology". Journal of Engineering and Technology Management - JET-M, 29, 528-545.

Parry, G., Bustinza, O. F. \& Vendrell-Herrero, F. (2012). "Servitisation and value co-production in the UK music industry: An empirical study of Consumer Attitudes". International Journal of Production Economics, 135, 320-332.

Paton, R. A. \& Mccalman, J. (2008). Change management: A guide to effective implementation, Sage.

Pawar, K. S., Beltagui, A. \& Riedel, J. C. K. H. (2009). "The PSO triangle: Designing product, service and organisation to create value". International Journal of Operations and Production Management, 29, 468-493.

Pettigrew, A. M. (1988). The management of strategic change, B. Blackwell.

Pettigrew, A. M. (2012). "Context and Action in the Transformation of the Firm: A Reprise". Journal of Management Studies, 49, 1304-1328.

Pezzotta, G., Cavalieri, S. \& Gaiardelli, P. (2012). "A spiral process model to engineer a product service system: An explorative analysis through case studies". CIRP Journal of Manufacturing Science and Technology, 5, 214-225.

Phumbua, S. \& Tjahjono, B. (2012). "Towards product-service systems modelling: A quest for dynamic behaviour and model parameters". International Journal of Production Research, $50,425-442$.

Ponsignon, F., Smart, P. A. \& Maull, R. S. (2012). "Process design principles in service firms: Universal or context dependent? A literature review and new research directions". Total Quality Management and Business Excellence, 23, 1273-1296.

Porter, M. and Ketels, C. (2003) UK Competitiveness: Moving to the Next Stage. London: Department of Trade and Industry.

Pye, A. \& Pettigrew, A. (2005). "Studying board context, process and dynamics: some challenges for the future". British Journal of Management, 16, S27-S38.

Raddats, C. (2011). "Aligning industrial services with strategies and sources of market differentiation". Journal of Business and Industrial Marketing, 26, 332-343.

Raddats, C. \& Burton, J. (2011). "Strategy and structure configurations for services within productcentric businesses". Journal of Service Management, 22, 522-539.

Raddats, C. \& Easingwood, C. (2010). "Services growth options for B2B product-centric businesses". Industrial Marketing Management, 39, 1334-1345.

Raddats, C. \& Kowalkowski, C. (2014). "A Reconceptualization of Manufacturers' Service Strategies". Journal of Business-to-Business Marketing, 21, 19-34.

Raddats, C. O. \& Burton, J. (2014). "Creating multi-vendor solutions: The resources and capabilities required". Journal of Business and Industrial Marketing, 29, 132-142.

Raja, J. Z., Green, S. D. \& Leiringer, R. (2010). "Concurrent and disconnected change programmes: Strategies in support of servitization and the implementation of business partnering". Human Resource Management Journal, 20, 258-276.

Rapaccini, M., Saccani, N., Pezzotta, G., Burger, T. \& Ganz, W. (2013). "Service development in product-service systems: A maturity model". Service Industries Journal, 33, 300-319.

Resta, B., Gaiardelli, P. \& Pezzotta, G. (2009). "Sustainability in the auto repair industry: A life cycle assessment application". International Journal of Product Lifecycle Management, 4, 146-165.

Robinson, T., Clarke-Hill, C. M. \& Clarkson, R. (2002). "Differentiation through service: A perspective from the commodity chemicals sector". Service Industries Journal, 22, 149-166.

Roehrich, J. K. \& Caldwell, N. D. (2012). "Delivering integrated solutions in the public sector: The unbundling paradox". Industrial Marketing Management, 41, 995-1007.

Roser, T., Defillippi, R. \& Samson, A. (2013). "Managing your co-creation mix: Co-creation ventures in distinctive contexts". European Business Review, 25, 20-41.

Roy, R. \& Cheruvu, K. S. (2009). "A competitive framework for industrial product-service systems". International Journal of Internet Manufacturing and Services, 2, 4-29.

Saccani, N., Visintin, F. \& Rapaccini, M. (2014). "Investigating the linkages between service types and supplier relationships in servitized environments". International Journal of Production Economics, 149, 226-238. 
Sakao, T., Ölundh Sandström, G. \& Matzen, D. (2009). "Framing research for service orientation of manufacturers through PSS approaches". Journal of Manufacturing Technology Management, 20, 754-778.

Santamaría, L., Jesús Nieto, M. \& Miles, I. (2012). "Service innovation in manufacturing firms: Evidence from Spain". Technovation, 32, 144-155.

Schmenner, R. W. (2009). "Manufacturing, service, and their integration: Some history and theory". International Journal of Operations and Production Management, 29, 431-443.

Self, D. R., Armenakis, A. A. \& Schraeder, M. (2007). "Organizational change content, process, and context: a simultaneous analysis of employee reactions". Journal of Change Management, 7, 211-229.

Settanni, E., Newnes, L. B., Thenent, N. E., Parry, G. \& Goh, Y. M. (2014). "A through-life costing methodology for use in product-service-systems". International Journal of Production Economics, 153, 161-177.

Shen, J., Wang, L. \& Sun, Y. (2012). "Configuration of product extension services in servitisation using an ontology-based approach". International Journal of Production Research, 50, 64696488.

Sheth, J. N. \& Sharma, A. (2008). "The impact of the product to service shift in industrial markets and the evolution of the sales organization". Industrial Marketing Management, 37, 260-269.

Smith, D. J. (2013). "Power-by-the-hour: The role of technology in reshaping business strategy at Rolls-Royce". Technology Analysis and Strategic Management, 25, 987-1007.

Smith, L., Maull, R. \& Ng, I. C. L. (2014). "Servitization and operations management: A service dominant-logic approach". International Journal of Operations and Production Management, $34,242-269$.

Smith, L., Ng, I. \& Maull, R. (2012). "The three value proposition cycles of equipment-based service". Production Planning and Control, 23, 553-570.

Spring, M. \& Araujo, L. (2009). "Service, services and products: Rethinking operations strategy". International Journal of Operations and Production Management, 29, 444-467.

Spring, M. \& Araujo, L. (2013). "Beyond the service factory: Service innovation in manufacturing supply networks". Industrial Marketing Management, 42, 59-70.

Srai, J. S. (2011). "Supply network integration in multi-organisational network systems". International Journal of Manufacturing Research, 6, 122-133.

Storbacka, K. (2011). "A solution business model: Capabilities and management practices for integrated solutions". Industrial Marketing Management, 40, 699-711.

Storbacka, K., Windahl, C., Nenonen, S. \& Salonen, A. (2013). "Solution business models: Transformation along four continua". Industrial Marketing Management, 42, 705-716.

Stremersch, S., Wuyts, S. \& Frambach, R. T. (2001). "The Purchasing of Full-Service Contracts:: An Exploratory Study within the Industrial Maintenance Market". Industrial Marketing Management, 30, 1-12.

Suarez, F. F., Cusumano, M. A. \& Kahl, S. J. (2013). "Services and the business models of product firms: An empirical analysis of the software industry". Management Science, 59, 420-435.

Sun, H. (2010). "Product service relationship: Defining, modelling and evaluating". International Journal of Internet Manufacturing and Services, 2, 128-141.

Sun, H., Wan, N., Chang, Z. \& Mo, R. (2011). "Approach to optimization of part machining service combination". International Journal of Advanced Manufacturing Technology, 56, 767-776.

Sun, H., Wang, Z., Zhang, Y., Chang, Z., Mo, R. \& Liu, Y. (2012). "Evaluation method of productservice performance". International Journal of Computer Integrated Manufacturing, 25, 150157.

Tan, A. R., Matzen, D., Mcaloone, T. C. \& Evans, S. (2010). "Strategies for designing and developing services for manufacturing firms". CIRP Journal of Manufacturing Science and Technology, 3, 90-97.

Teixeira, E. L. S., Tjahjono, B. \& Alfaro, S. C. A. (2012). "A novel framework to link Prognostics and Health Management and Product-Service Systems using online simulation". Computers in Industry, 63, 669-679. 
Teixeira, E. L. S., Tjahjono, B., Alfaro, S. C. A. \& Julião, J. M. S. (2013). "Harnessing prognostics health management and product-service systems interaction to support operational decisions". Journal of Manufacturing Technology Management, 24, 78-94.

Thomas, A. J., Byard, P. \& Evans, R. (2012). "Identifying the UK's manufacturing challenges as a benchmark for future growth". Journal of Manufacturing Technology Management, 23, 142156.

Thomas, O., Walter, P., Blinn, N. \& Schlicker, M. (2009). "IT-supported value-added chains for the integration of products and services". International Journal of Internet Manufacturing and Services, 2, 43-55.

Todnem By, R. (2005). "Organisational change management: A critical review". Journal of Change Management, 5, 369-380.

Tongur, S. \& Engwall, M. (2014). "The business model dilemma of technology shifts". Technovation, 34, 525-535.

Toossi, A., Lockett, H. L., Raja, J. Z. \& Martinez, V. (2013). "Assessing the value dimensions of outsourced maintenance services". Journal of Quality in Maintenance Engineering, 19, 348363.

Tranfield, D., Denyer, D. \& Smart, P. (2003). "Towards a methodology for developing evidence-informed management knowledge by means of systematic review". British Journal of Management, 14, 207-222.

Tukker, A. (2004). "Eight types of product-service system: eight ways to sustainability? Experiences from SusProNet". Business strategy and the environment, 13, 246-260.

Turunen, T. \& Finne, M. (2014). "The organisational environment's impact on the servitization of manufacturers". European Management Journal, 32, 603-615.

Turunen, T. T. \& Toivonen, M. (2011). "Organizing customer-oriented service business in manufacturing". Operations Management Research, 4, 74-84.

Ulaga, W. \& Loveland, J. M. (2014). "Transitioning from product to service-led growth in manufacturing firms: Emergent challenges in selecting and managing the industrial sales force". Industrial Marketing Management, 43, 113-125.

Ulaga, W. \& Reinartz, W. J. (2011). "Hybrid offerings: how manufacturing firms combine goods and services successfully". Journal of Marketing, 75, 5-23.

Van Ostaeyen, J., Van Horenbeek, A., Pintelon, L. \& Duflou, J. R. (2013). "A refined typology of producteservice systems based on functional hierarchy modeling". Journal of Cleaner Production, 51, 261-276.

Vandermerwe, S. \& Rada, J. (1988). "Servitization of business: Adding value by adding services". European Management Journal, 6, 314-324.

Velamuri, V. K., Neyer, A. K. \& Möslein, K. M. (2011). "Hybrid value creation: A systematic review of an evolving research area". Journal fur Betriebswirtschaft, 61, 3-35.

Visintin, F. (2012). "Providing integrated solutions in the professional printing industry: The case of Océ". Computers in Industry, 63, 379-388.

Wang, C. H. (2014). "Does service innovation matter in high-tech industry?". Journal of Technology Management and Innovation, 9, 42-55.

Wang, K., Jiang, Z., Li, N. \& Geng, N. (2013). "Optimal production and admission control for a stochastic SOM system with demands for product and PSS". International Journal of Production Research, 51, 7270-7288.

Wang, X. \& Durugbo, C. (2013). "Analysing network uncertainty for industrial product-service delivery: A hybrid fuzzy approach". Expert Systems with Applications, 40, 4621-4636.

Wheelen, T. L. \& Hunger, J. D. (2011). Concepts in strategic management and business policy, Pearson Education India.

Whipp, R., Rosenfeld, R. \& Pettigrew, A. (1989). "Culture and competitiveness: evidence from two mature UK industries". Journal of Management Studies, 26, 561-585.

Wikhamn, B. R., Ljungberg, J. \& Styhre, A. (2013). "Enacting hard and soft product offerings in mature industries: Moving towards servitisation in volvo". International Journal of Innovation Management, 17.

Wild, P. J. (2010). "A systemic framework for supporting cross-disciplinary efforts in services research". CIRP Journal of Manufacturing Science and Technology, 3, 116-127. 
Windahl, C. \& Lakemond, N. (2006). "Developing integrated solutions: the importance of relationships within the network". Industrial Marketing Management, 35, 806-818.

Wise, R. \& Baumgartner, P. (1999). "Go downstream: the new profit imperative in manufacturing". Harvard business review, 77, 133-141.

Wit, B. D., Meyer, R. \& Heugens, P. (2010). Strategy: process, content, context-an international perspective, UK, South-Western Cengage Learning.

Witell, L. \& Löfgren, M. (2013). "From service for free to service for fee: Business model innovation in manufacturing firms". Journal of Service Management, 24, 520-533.

Xie, W., Jiang, Z., Zhao, Y. \& Shao, X. (2014). "Contract design for cooperative product service system with information asymmetry". International Journal of Production Research, 52, $1658-1680$.

Yang, B., Yang, Y. \& Williams, S. (2010). "Service postponement: Translating manufacturing postponement to service operations". Journal of Manufacturing Technology Management, 21, 470-483.

Zhen, L. (2012). "An analytical study on service-oriented manufacturing strategies". International Journal of Production Economics, 139, 220-228. 